\title{
TSC1 Gene
}

National Cancer Institute

\section{Source}

National Cancer Institute. TSC1 Gene. NCI Thesaurus. Code C18259.

This gene is involved in cell cycle regulation and the loss of cellular adhesion. 